\title{
Superparasitism by Torymus cyanimus (Hymenoptera: Torymidae) in the Volga-Kama region
}

\author{
VLADIMIR M. BASOV \\ Department of Animal Ecology, Udmurt State University, Universitetskaya 1, Izhevsk, Russia, 426034; e-mail: basov@uni.udm.ru
}

Key words. Torymus cyanimus, Torymidae, parasitoids, Eurytoma serratulae, E. robusta, Urophora cardui, Cirsium setosum, hyperparasitism, multiparasitism, superparasitism

\begin{abstract}
On the basis of a twenty-year investigation, the life-cycle of Torymus cyanimus Boheman (Hymenoptera: Torymidae), a hyperparasitoid of a gall-forming fly in the Volga-Kama region is described. This parasitoid is the top-consumer in a food chain on Cirsium setosum (Willdenow) Iljin, in which the herbivore is Urophora cardui L. (Diptera: Tephritidae) and the primary parasitoids belong to the genus Eurytoma (Hymenoptera: Eurytomidae). Mating and oviposition behaviour were studied, and the superparasitism and larval cannibalism investigated in the second parasitoid generation. The superparasitism in T. cyanimus evolved in connection with the ovipositor elongation, leading to eggs being laid later when the fly host has already been completely consumed by larvae of Eurytoma serratulae F. Hyperparasitism and larval cannibalism in the second generation of T. cyanimus might account for the evolution of hyperparasitism in this species.
\end{abstract}

\section{INTRODUCTION}

Torymus cyanimus Boheman is a typical representative of the family Torymidae, which are parasites of flies that live in plant galls and mines. Its larvae are ectoparasitic on larvae of gall-forming flies of the family Tephritidae (Askew, 1980). Many torymid species are primary parasitoids and some are also facultatively multiparasitic (Weis, 1982). (Two or more parasitoids attack together one host larva). This results in rather complex relationships between the different parasites species, as well as between the parasitoids and the larvae of the gall fly.

Urophora cardui L. is a highly specialized gall-former living in the stems of creeping thistle, Cirsium arvense (Linnaeus) Scopoli. In western Europe its larvae are attacked by Eurytoma serratulae F., Eurytoma robusta Mayr, Torymus chloromerus Walker and Pteromalus elevatus Walker. The incidence of ectoparasitism may be very high (93.2-96.0\%) (Frenzel et al., 2000). Eurytoma serratulae is a specialist parasitoid of $U$. cardui. It attacks Urophora larvae at an early stage in their development, when the gall is small. Females of E. serratulae are unable to attack tephritid fly larvae in large galls. The length of its ovipositor limits this wasp to laying its eggs on host larvae in the central cells of large galls. The thickness of the gall wall determines the availability of a concealed host (Weis, 1982; Weis et al., 1985).

In eastern Europe Tephritid larvae are attacked by different species of Eurytoma sp. and Torymids. The life cycle and the behaviour of Torymids have been poorly investigated.

The purpose of the present study was to describe certain aspects of the reproduction, biology, and behaviour of adult Torymus cyanimus in the Volga-Kama region and reconstruct the stages in the evolution of hyperparasitism and superparasitism by this species. (Hyperparasitism one species parasites upon another parasitic species; sec- ondary parasitoid or more. Superparasitism - the parasite puts into a host more eggs than the host can survive).

\section{MATERIALS AND METHODS}

All observations were made between 1979-1999 near the small town of Tetjushi (1979-1989) on the right bank of the Volga River (Pre-Volga region) and the town of Yelabuga (1989-1999) on the right bank of the Kama River (Pre-Kama region). Galls were collected between the beginning of September and the end of October. Three hundred and fifty seven galls of $U$. cardui were observed in the field until the second generation of ectoparasitoids emerged (between the end of August and the end of September). In addition, oviposition by $T$. cyanimus was observed in the field, the entire cycle of reproductive behaviour (mating, oviposition, courtship, and copulation behaviour) and the life cycle of the parasitoids were observed in the laboratory. All of the specific display behaviours of T. cyanimus were noted and photographed. Two hundred and forty one galls of $U$. cardui were dissected (1979-1985) and the state of the fly larvae and their parasites assessed in the field. After each dissection a gall was reassembled and tied together with string to conserve its natural appearance and retain a suitable environment for the host. The larvae of the flies and parasitoids in the dissected galls did not die and adults emerged normally from gall cells; this indicates that the manipulations of the galls did not interfer with larval development. The state and content of the dissected galls were checked every ten days and the observations ended when either the gall or the plant died (between the end of September and the beginning of October). At that time the galls were collected and the observations on larval development continued in the laboratory until the emergence of the adult insects. In seventy three of these galls the tephritid larvae and parasitoids were killed by birds, ants or larvae of polyphagous Noctuidae, and eighty seven of the galls were lost during the period of observation in the field.

From different populations of $U$. cardui in the Pre-Volga region 1304 stem galls were collected, of these 919 were dissected, but the full life cycle (from the beginning of gallformation to the end of the emergence of flies and parasitoids) was only determined for 546 stem galls. In the Pre-Kama region 

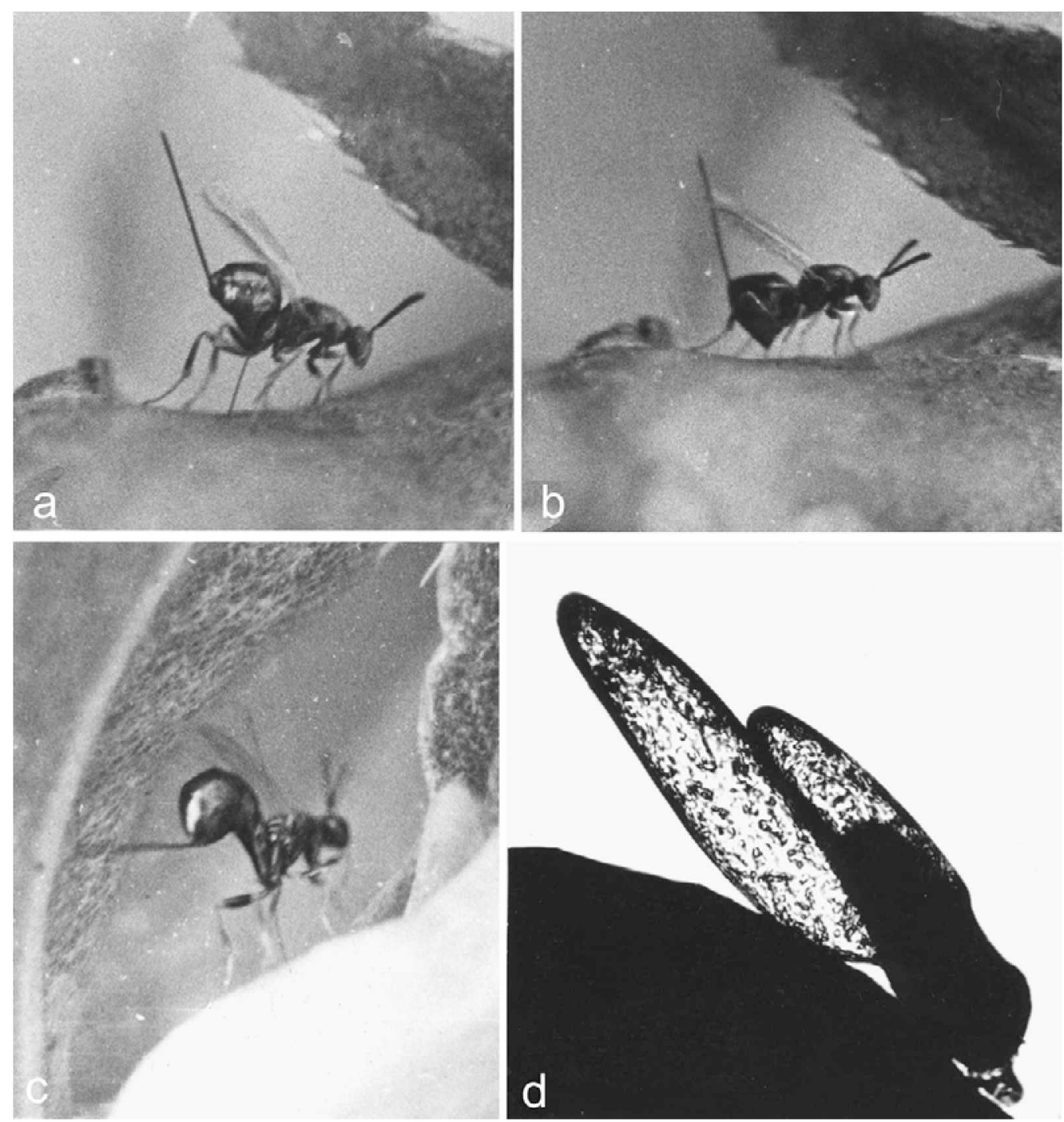

Fig. 1. a-oviposition by Torymus cyanimus. The female selects a place for oviposition, abdomen is raised upwards, antennae vigorously palpate the surface; $b$ - a place is chosen, ovipositor inserted, and then $2 / 3$ of its length protruded into the gall. If unsuccess$\mathrm{ful}$, the female removes its ovipositor from the gall and inserts it into the gall at a new point; $\mathrm{c}$ - process of oviposition. The female has inserted the whole ovipositor into the gall; $\mathrm{d}-2$ ectoparasitoids eggs attached to a puparium of the gall-forming fly that contains larvae of the endoparasitoid, E. serratulae

220 stem galls were collected and dissected, but the full life cycle of the insects was only monitored in 183 galls (Table 1). In other dissected galls, the larvae of Urophora and the parasitoids died in the laboratory during winter. After measuring the diameter and volume of the galls, they were dissected to estimate incidence of parasitism and other causes of mortality of $U$. cardui. The percentage of hosts killed by each parasitoid species was calculated from this data.

All gall flies and parasitoids were reared from the collected galls. The emerged insects were used for experimental purposes. Pairs of adult $T$. cyanimus were each placed under a glass cover together with dissected galls that were occupied by either fly larvae or parasitoid larvae. After every examination the gall sections were tied together with a thread. The galls were checked every 10 days (over a month) and every 20 days after that. As soon as the insects emerged from the galls, the observations were discontinued.

\section{RESULTS AND DISCUSSION}

\section{Main hosts and life cycle of Eurytoma}

$U$. cardui has a univoltine life cycle. In the VolgaKama region $U$. cardui lives only in Cirsium setosum (Willdenow) Iljin. Flies overwinter within galls as last instar larvae and pupation occurs the next spring. Adult $U$. cardui usually appear in the field between the end of May and the beginning of June.

Mating takes place 5-7 days after emergence and then immediately females begin ovipositing in shoots of Cirsium setosum. The galls are induced by the second instar larvae (Lalonde \& Shorthouse, 1985; Frenzel et al., 2000). In the Volga-Kama region galls are formed in the first half of July. Each larva feeds in a separate cell and the number of cells within each gall varies. Tephritid females generally lay 12-20 eggs. Eggs and first instar larvae died when forming galls, if there were only 3-4 cells (min $1-\max 20$; mean $3.89 \pm 0.11$ ). 

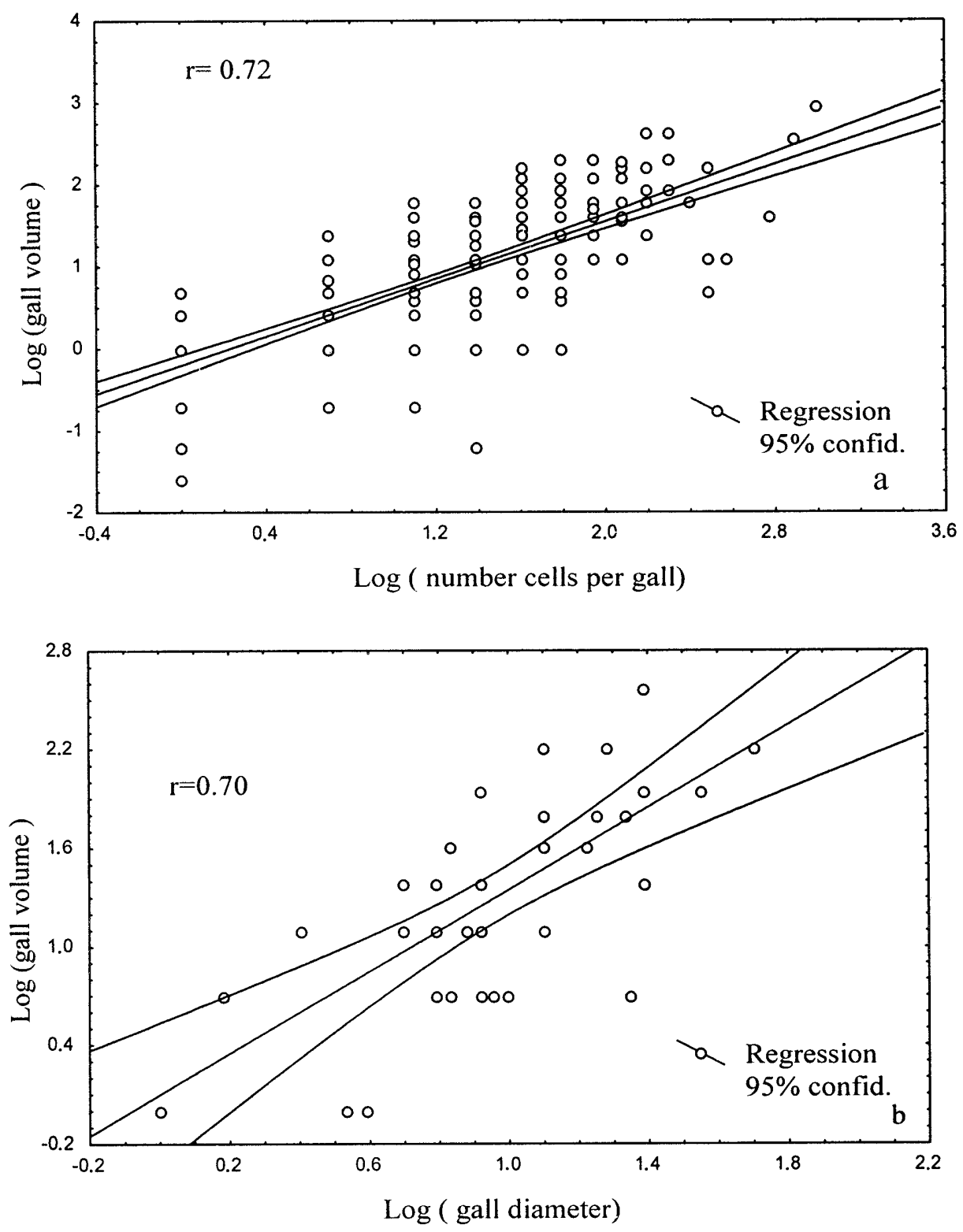

Fig. 2. The number of cells within a gall is correlated with gall volume (a) $(\mathrm{r}=0.72, \mathrm{df}=321 ; \mathrm{y}=-0.2+0.87 \mathrm{x} ; \mathrm{P}<0,05)$ and gall volume is correlated with gall diameter $(b)(r=0.70, d f=71 ; y=0.1+1.25 x ; P<0,05)$.

Young $U$. cardui larvae were attacked by the endoparasitoid Eurytoma serratulae and the polyphagous ectoparasitoid E. robusta. In the Volga-Kama region larvae of flies attacked by the endoparasitoid $E$. serratulae pupated in August, and within each puparium only one Eurytoma larva overwintered. Pupation of the parasitoid larvae occurs in spring, usually in May. The pupa develops within 2-3 weeks. Adult parasitoids emerged between late May and early June. Mating takes place on the host's feeding plant, C. setosum. Larval development occurs within the larva of the host fly (Wangberg, 1980). Other studies have reported that E. serratulae and E. robusta may kill all of the larvae Urophora cardui in a local population (Eber \& Brandel, 1994; Frenzel et al., 2000).

In the Pre-Volga region I dissected 546 galls of $U$. cardui. They contained a total of 2126 cells. Furthermore, the 708 Urophora larvae (691 living, 17 dead for unknown reasons) contained three parasitoid species known to feed on the larvae of $U$. cardui. A total of 970 individuals of the endoparasitoid E. serratulae were reared from dissected galls, 249 of the ectoparasitoid $E$. robusta, and 68 of the hyperparasitoid T. cyanimus. Twenty seven Urophora larvae were eaten by larvae of Lepidoptera (Noctuidae [25], Geometridae [2]). One hundred and four cells were empty.

\section{Biology and behaviour of Torymus cyanimus}

T. cyanimus is a parasitoid of different species of gallforming flies. The last instar larvae of $T$. cyanimus overwinter in galls. Pupation takes place between late April and early May. The pupa develops within 2-3 weeks.

As a rule, males emerge 7-10 days before females. In the beginning of May it is possible to find a few individuals, but the main appearance in the field occurs between May and the beginning of June. Adults feed on the 
TABLE 1. Cells per gall and percentage parasitism of $U$. cardui in the Pre-Volga and Pre-Kama regions.

\begin{tabular}{|c|c|c|c|c|c|c|}
\hline \multirow{3}{*}{ Years } & \multirow{3}{*}{$\begin{array}{l}\text { Number of dis- } \\
\text { sected galls }\end{array}$} & \multirow{3}{*}{ Mean cells/gall } & \multirow{3}{*}{$\begin{array}{l}\text { Percent living } \\
\text { flies }\end{array}$} & \multicolumn{3}{|c|}{ Percentage of parasitism } \\
\hline & & & & \multirow{2}{*}{ E. serratulae } & \multicolumn{2}{|c|}{ Ectoparasitoids } \\
\hline & & & & & E. robusta & T. cyanimus \\
\hline \multicolumn{7}{|c|}{ Locality: oak forest. Tetjushi, Tatarstan, Pre-Volga } \\
\hline 1979 & 101 & 6.1 & 41.4 & 48.9 & 7.1 & 1.6 \\
\hline 1980 & 44 & 3.2 & 45.8 & 39.4 & 6.3 & 5.6 \\
\hline 1981 & 116 & 3.8 & 26.4 & 44.6 & 15.1 & 2.3 \\
\hline 1982 & 105 & 2.8 & 15.1 & 43.6 & 21.3 & 13.1 \\
\hline 1983 & 19 & 4.2 & 11.3 & 81.3 & 6.3 & 2.5 \\
\hline 1984 & 48 & 3.3 & 39.7 & 39.7 & 12.2 & 0.0 \\
\hline 1985 & 45 & 3.0 & 35.6 & 33.7 & 14.8 & 0.0 \\
\hline 1987 & 8 & 3.1 & 28.0 & 64.0 & 0.0 & 0.0 \\
\hline 1988 & 40 & 4.6 & 49.5 & 32.6 & 10.9 & 0.0 \\
\hline 1989 & 20 & 2.7 & 18.9 & 66.0 & 5.7 & 0.0 \\
\hline mean & & 3.7 & 31.1 & 49.7 & 10.0 & 2.5 \\
\hline \multicolumn{7}{|c|}{ Locality: pine forest and flood plain forest. Yelabuga, Tatarstan, Pre-Kama } \\
\hline 1989 & 13 & 2.6 & 35.3 & 38.2 & 20.6 & 0.0 \\
\hline 1990 & 27 & 3.9 & 63.0 & 25.9 & 7.4 & 0.0 \\
\hline 1991 & 44 & 4.7 & 47.4 & 42.7 & 5.3 & 0.0 \\
\hline 1992 & 21 & 4.2 & 26.4 & 30.7 & 10.2 & 0.0 \\
\hline 1993 & 28 & 3.9 & 42.6 & 37.7 & 9.7 & 0.0 \\
\hline 1994 & 11 & 4.5 & 20.3 & 55.1 & 22.4 & 0.0 \\
\hline 1995 & 24 & 5.3 & 48.2 & 30.5 & 16.7 & 0.0 \\
\hline 1999 & 15 & 5.8 & 34.8 & 45.5 & 0.0 & 0.0 \\
\hline mean & & 4.4 & 39.7 & 38.3 & 11.5 & 0.0 \\
\hline
\end{tabular}

flowers of weeds as they need nectar. As in other species of the genus, T. cyanimus has two generations per year (Weis, 1983). In the Volga-Kama region, emergence of the summer generation occurs between late August and early September. Some days after emergence from galls, male and female parasitoids begin to search for mating partners. Females leave odour marks on plant leaves (Weis, 1983) and mating takes place on the host plant of the gall fly or other flowering plants of the family Asteraceae.

Laboratory experiments showed that the courting ritual of $T$. cyanimus was rather complex; it included short flights and cleaning of antennae, legs, abdomen and copulative organs. This lasts from 40 minutes to several hours, after which mating takes place and females begin to search for host galls. At firs $7 \mathrm{t}$ shoots and leaves of host plants are examined. Having found a gall, a Torymus female starts to actively clean her antennae, legs and abdomen. Examination of a gall and adjacent parts of a plant may interrupt the cleaning. Several times the female walks round and about the gall, touching it with her antennae to determine where to insert her ovipositor. Larvae situated near the surface of a gall are preferred because females are unable to lay eggs on larvae and pupae they cannot reach with their ovipositor (Fig. 1). Eggs of this ectoparasitoid are more often laid in small galls (volume $0.5-4 \mathrm{ml}$, diameter $0.5-1.5 \mathrm{~mm}$ ). The maximum volume of gall found was $19 \mathrm{ml}$ with 20 cells and gall volume correlated positively with gall diameter (Fig. 2b). Furthermore, the number of cells was correlated with gall volume (Fig. 2a).

As the gall volume increased, the number of Eurytoma larvae per gall also increased, particularly when the gall volume was more than $10 \mathrm{ml}$. Although the proportion of cells with Eurytoma larvae fluctuated, the percentage of gall-forming fly larvae that survived decreased with increasing gall volume (Fig. 3, 4a, c). At present, we cannot explain these phenomena. It is known that Eurytoma females lay eggs in small galls (Weis et al., 1985). T. cyanimus only inhabits small galls in the Volga-Kama region. T. cyanimus did not oviposit in galls with a volume of more than $5-7.5 \mathrm{ml}$ (Fig. 4a).

The number of cells per gall was positively correlated with the number of parasitised fly larvae (Fig. 5) (correlation for $E$. serratulae $\mathbf{r}=0,61, \mathbf{n}=391, \mathrm{P}<0,001$; for $E$. robusta $\mathbf{r}=0,18, \mathrm{n}=154, \mathrm{P}<0,001)$. Thus the increase in gall dimensions leads to increased mortality of fly larvae via increased incidence of parasitism. The highest survival of flies was observed in average-sized galls (Fig. 3-5).

Examination of galls by parasitoid females is guided by vibration and sounds produced by the movements of Eurytoma larvae, which help the females to locate the host larvae (Lawrence, 1981), and to select oviposition sites. Additional probes are made in different parts of the gall (Fig. 1a, b). T. cyanimus females find an optimal oviposition point by probing with their ovipositor a number of times which enables the parasitoid to find a host more quickly (Lawrence, 1981). Having found an appropriate site for oviposition a female cleans itself and then begins to oviposit into the gall by extending its ovipositor while sitting on the gall (Fig. 1c). Antennae move constantly and sometimes the female vibrates its abdomen and wings. Oviposition time varies, but can last for up to several hours. The female occasionally interrupts oviposition and starts cleaning. Thereafter, the female walks over the 


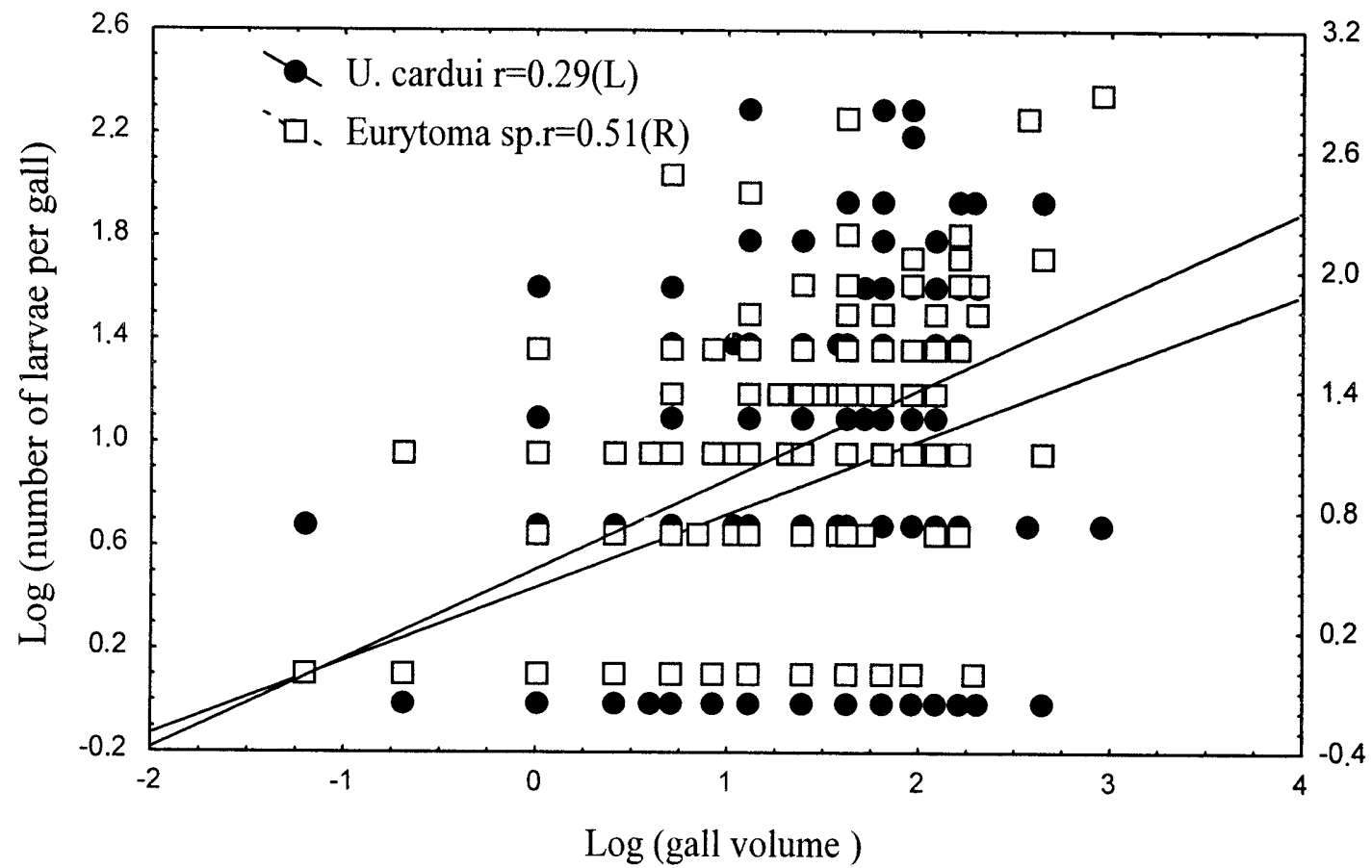

Fig. 3. The number $U$. cardui and Eurytoma sp. larvae in relation to the volume of a gall. (U. cardui, $\mathrm{y}=0.44+0.28 \mathrm{x}, \mathrm{n}=210$; Eurytoma sp., $\mathrm{y}=0.51+0.45 \mathrm{x}, \mathrm{n}=251 ; \mathrm{P}<0.05)$.

gall, deposits odour marks and than returns to the original site.

T. cyanimus has white eggs of length $0.8-1 \mathrm{~mm}$ and diameter $0.18-0.25 \mathrm{~mm}$. They are semi-transparent and have a small protrusion at one end. $T$. cyanimus females attach 2-4 eggs to the anterior part of a puparium (Fig. 1d). In September 1981, I saw a female lay 34 eggs over a period of 3 hours on one puparium. The puparium contained a last instar endoparasitoid larva (family Eurytomidae). Sixteen galls were found in which 8 Torymus eggs were located on one puparium. In the gall in which 34 eggs were laid on one puparium, there were 4 cells each containing a puparium with an endoparasitoid larva. Although all of these pupae were accessible to the Torymus female, she laid all her eggs on one pupa. In the process of oviposition the female examined the gall many times in several places, but always returned to the same oviposition site. It is unclear why the female laid so many eggs on one puparium and did not parasitize host larvae in the other cells, from which E. serratulae hatched in spring.

In the same year an aggregation of 11 ectoparasitoid females were observed on one gall. They quickly flew from one place to another, crawled over the gall and the plant, vibrated their wings, but did not leave. After about an hour the females flew off. When the gall was dissected 14 ectoparasitoid eggs were found on one puparium.

If a second female of the parasitoid (T. cyanimus) lays many eggs on one Eurytoma larva, the first born $T$. cyanimus larva initially feeds on the other eggs and on Torymus larvae that hatch later. Only one ectoparasitoid larva survives and eats the host larva. Such larval cannibalism and facultative multiparasitism is characteristic of many insects including a number of Torymidae (Askew,
1980; Weis, 1982). Torymus larvae can feed on the tissues of a gall, when the host larva is insufficient for the parasite to complete its development (Weis, 1983).

\section{CONCLUSION}

The gall-forming fly $U$. cardui develops on C. setosum and may be a major controlling agent in agroecosystems and other plant associations. Three hymenopteran parasitoid species develop upon its larvae (E. serratulae, $E$. robusta and $T$. cyanimus ). They make up a trophic chain feeding on C. setosum, with the primary consumer, $U$. cardui, attacked by two primary parasitoids of the genus Eurytoma and a top-consumer, the hyperparasitoid $T$. cyanimus. According to Tobias (1978) T. cyanimus is a typical representative of an asynchronous secondary parasitoid. The evolution of hyperparasitism in this particular case can be understood and explained as this species was once a parasitoid of gall-forming flies, adapted to mass oviposition in the puparia of the host fly. In these circumstances Torymus larvae usually complete their development. If oviposition by an ectoparasitoid coincids with that of an endoparasitoid, multiparasitism occurs. It is known that torymids may be facultatively multiparasitic (Weis, 1982). However, this has evidently proved to be evolutionarily unstable because in such a situation one of the competing parasitoids is doomed to perish. Later oviposition by $T$. cyanimus becomes possible only if it develops a longer ovipositor. Galls grow and the longer the ovipositor a female has, the later it can lay its eggs. It is possible that Torymus primarily developed upon larvae of a gall-forming fly. This sometimes occurs in nature when its larvae bore into puparia and feed upon the internal contents (e.g. the fly's pupa or Eurytoma larva) which has proved to be less advantageous. At the time 

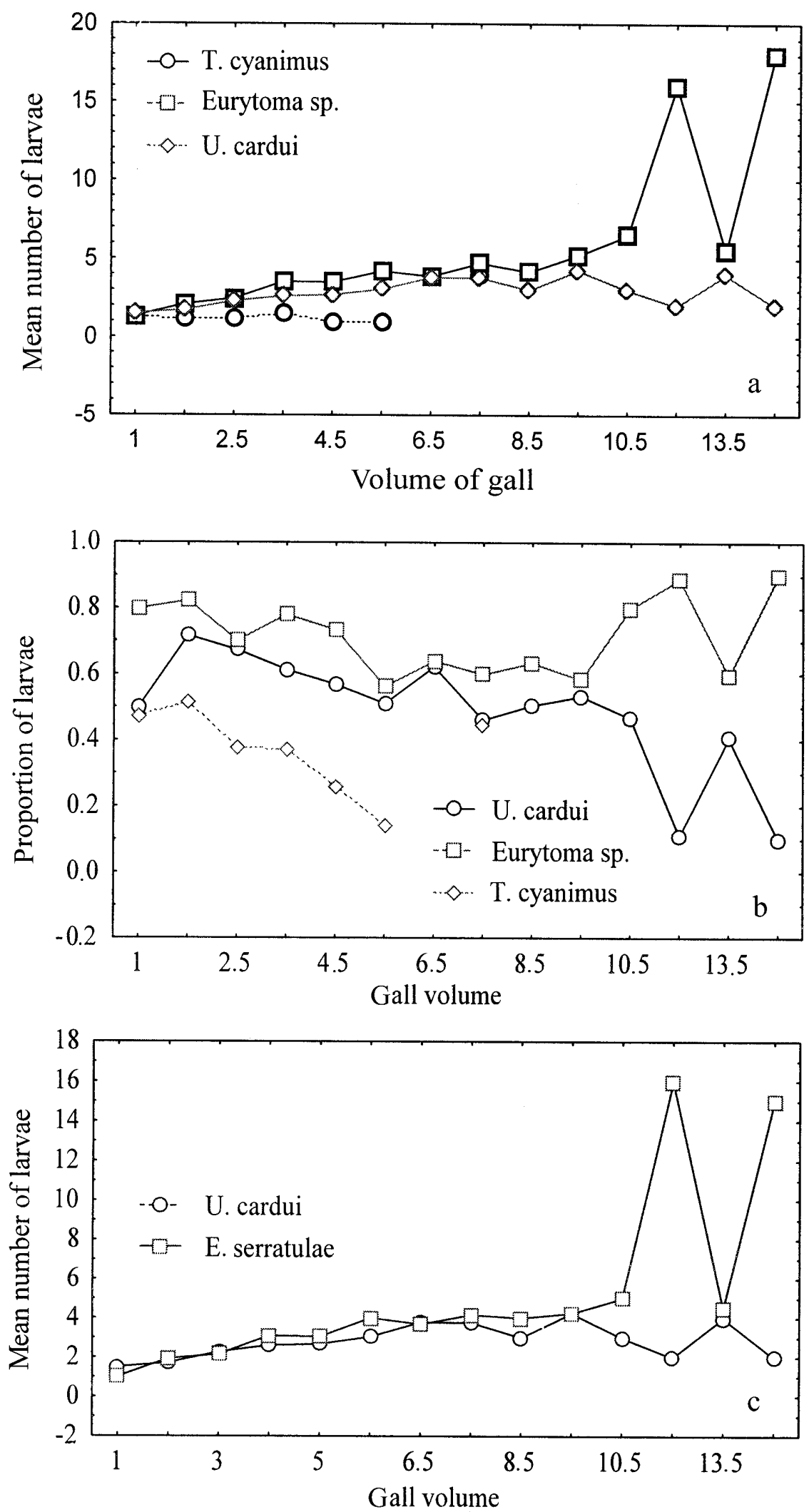

Fig. 4. a - survival and mortality of $U$. cardui, Eurytoma sp. (E. serratulae + E. robusta) and T. cyanimus larvae in relation to their number and the volume of a gall. These mortality factors decrease with increase in number of gall cells. Correlation: gall volume $/ T$. cyanimus larvae $\mathrm{r}=0.31, \mathrm{n}=27, \mathrm{P}<0.05 ; \mathrm{b}$ - survival ratio of $U$. cardui, Eurytoma $\mathrm{sp}$. and T. cyanimus larvae related to gall volume. Correlation: gall volume / proportion Urophora larvae $\mathrm{r}=-0.25, \mathrm{n}=210$; gall volume / proportion Eurytoma larvae $\mathrm{r}=-0.20, \mathrm{n}=251$; gall volume / proportion T. cyanimus larvae $\mathrm{r}=-28, \mathrm{n}=27$; Urophora larvae / Eurytoma $\mathrm{sp}$. larvae $\mathrm{r}=-0.77, \mathrm{n}$ $=164$; Urophora larvae / T. cyanimus larvae $\mathrm{r}=0.47, \mathrm{n}=15 ;$ Eurytoma $\mathrm{sp} . /$ T. cyanimus $\mathrm{r}=-0.52, \mathrm{n}=28$, all $\mathrm{P}<0.05 ; \mathrm{c}-$ mean number of larvae of $U$. cardui, E. serratulae relative to gall volume. Correlation: gall volume / number E. serratulae $\mathrm{r}=0.51, \mathrm{n}=$ 217 ; U. cardui / E. serratulae $\mathrm{r}=-0.17, \mathrm{n}=155, \mathrm{P}<0.05$ 

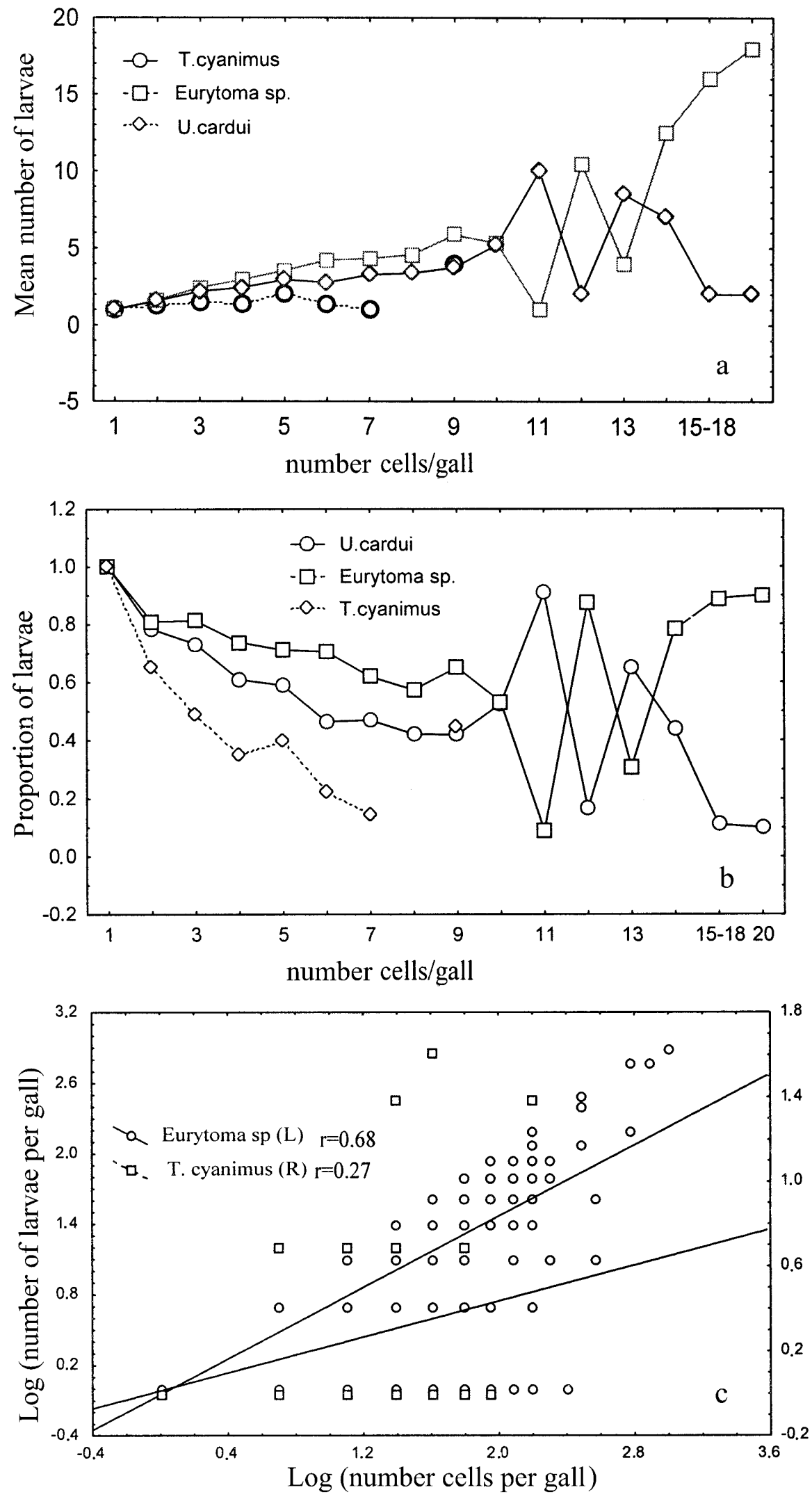

Fig. 5. a - the relation between survival and mortality of $U$. cardui, Eurytoma sp. and T. cyanimus larvae and to the number of cells per gall. Correlation: $\mathrm{N}$ cell per gall / $\mathrm{n}$ Urophora larvae $\mathrm{r}=0.39, \mathrm{n}=270 ; \mathrm{N}$ cell per gall $/ \mathrm{n}$ Eurytoma $\mathrm{sp} . \mathrm{r}=73, \mathrm{n}=391 ; \mathrm{N}$ cell per gall $/ \mathrm{n}$ T. cyanimus $\mathrm{r}=0.25, \mathrm{n}=47 ; \mathrm{b}$ - survival ratio of $U$. cardui, Eurytoma $\mathrm{sp}$. and T. cyanimus larvae related to the number of cells per gall; $\mathrm{c}-$ the relation between the number Eurytoma sp. and T. cyanimus larvae and the number cells per gall. (Eurytoma sp. $\mathrm{y}=0.048+0.76 \mathrm{x} ;$ T. cyanimus $\mathrm{y}=0.014+0.21 \mathrm{x} ; \mathrm{P}<0.05$ ). 
when Torymus oviposits most of the $U$. cardui larvae have been eaten by $E$. serratulae. Thus, successful Torymus larvae have acquired the ability to feed on Eurytoma larvae and develop as hyperparasitoids.

During oviposition, females of the second ectoparasitoid generation sometimes lay many eggs on the surface of a host larva. As a result, larval cannibalism supplies the first instar larvae with easily accessible protein food and in the long run results in a large number of individuals surviving. Utilization of siblings as a resource enhances ectoparasitoid development and helps the strongest to survive the winter.

However, many details of the biology of T. cyanimus still remain unknown. For example, I collected adult parasitoids in different biotopes in the Pre-Kama region but did not find their larvae in galls of $U$. cardui (Table 1). This suggests that hyperparasitism by $T$. cyanimus in specific galls is connected with very low population sizes or it has another host in this region.

In particular, we do not know on which host and how the summer generation of the ectoparasitoid develops in the Volga-Kama region and the mode of feeding of the larvae is not well investigated. Further studies on the population dynamics and host specialization in the different populations are needed.

\section{REFERENCES}

Askew R.R. 1980: The diversity of insect communities in leaf mines and plant galls. J. Anim. Ecol. 49: 817-829.

EBer S. \& BRANDEL R. 1994: Ecological and genetic spatial patterns of Urophora cardui (Diptera: Tephritidae) as evidence for population structure and biogeographical processes. $J$. Anim. Ecol. 63: 187-199.

Frenzel M., Eber S., Klotz S. \& Brandel R. 2000: Ecological comparisons across geographical distributions; the thistle gall fly Urophora cardui (Diptera: Tephritidae) on two different Cirsium hosts. Eur. J. Entomol. 97: 183-189.

Lalonde R.G. \& Shorthouse J.D. 1985: Growth and development of larvae and galls of Urophora cardui (Diptera: Tephritidae). Oecologia 65: 161-165.

LAWRENCE P.O. 1981: Host vibration - a cue to host location by the parasite Biosteres longicaudatus. Oecologia 48: 249-251.

ToBIAS V.I. 1978: Hymenoptera. Introduction. In Keys for Animals of the European Part of USSR. Vol. 3. Nauka, Leningrad, pp. 7-42. [in Russian]

WANGBERG J.K. 1980: Comparative biology of gall-formers in the genus Procecidochares (Diptera: Tephritidae) on rabbitbrush in Idaho. J. Kansas Entomol. Soc. 53: 401-420.

WEIS A.E.1982: Resource utilization patterns in a community of gall-attacking parasitoids. Environ. Entomol. 11: 809-815.

WeIs A.E. 1983: Patterns of parasitism by Torymus capite on hosts distributed in small patches. J. Anim. Ecol. 52: 867-877.

Weis A.E., Abrahamson W.G. \& McCrea D. 1985: Host gall size and oviposition success by the parasitoid Eurytoma gigantea. Ecol. Entomol. 10: 341-348.

Received February 21, 2001; revised October 12, 2001, accepted January 5, 2002 